\title{
What Owners Expect From Their Woodlots
}

\author{
by
}

Alex Dickson 1

\begin{abstract}
There is no typical or average woodlot owner. Woodlot owners come from all walks of life and own woodlots for almost as many reasons as there are variations in the human personality. Some own woodlots for the primary purpose of producing some kind of cash crop: timber, Christmas trees, maple syrup, firewood, and so on. Others derive satisfaction from the nonconsumptive values of woodlot ownership, for example a scenic environment in which to hike, picnic, or meditate. The important thing to realize is that woodlot management has to address the expectations of the various owners if it is to stand a chance of being implemented. Findings made in the recent New Brunswick Private Woodlot Resources Study are discussed.
\end{abstract}

Key words: Woodlots, owner expectations, reasons for ownership, financial and nonfinancial goals.

\section{Introduction}

"What do owners expect from their woodlots?" is the primary question I was asked to address. However, there are three other questions that need to be considered along with it. These are: "What causes owners to expect what they do?", "Can owners realize what they expect?", and "If not, should society step in and lend a hand?"

First, the forest or woodlot is not perceived by everyone in the same way. People value it differently according to their needs and interests. As Shirley (1952) observed:

To a logger, it is a source of timber and pulpwood; to an ecologist, it is one of nature's grandest biologic communities; to a water user, it is a regulator of streamflow; to an artist, it is a source of creative inspiration; and to the forester, it is all these and more, because his concept includes the trees, everything that affects their growth and value, and all that the forest yields of any worth to man.

Woodlot owners' expectations of their woodlots may be tangible or intangible, financial or nonfinancial, depending on their personal values. Such values are gained from, and reinforced by, family, friends, school and youth groups in the process known to sociologists as socialization. Woodlot owners' expectations are influenced also by knowledge of their woodlots' capability for providing certain desirable goods and services (Dickson 1983).

The woodlot owners' circumstances, too, have a role to play. These determine to what extent the owners have time, energy, equipment and expertise to carry out activities essential to achieving certain goals. There are many kinds of woodlot owners: full-time farmers, part-time farmers, resident nonfarmers and nonresident nonfarmers. There are those who purchased their rural properties and those who inherited them.

1 Professor of Forestry, University of New Brunswick, and Executive Director of the New Brunswick Private Woodlot Resources Study, 1981-83.
Indeed, there are owners who inherited some and bought some. It must also be said that some had ownership of woodlots thrust upon them in that they bought either a farm or rural building lot and found that the trees were included in the deal.

The objectives of woodlot ownership reflect the needs or wants that owners are seeking to satisfy in owning woodland. Thus, they are a guide to what will motivate these owners in terms of management or the practice of forestry. Satisfaction of individual needs - those gaps between present and desired situations - is seen by many social scientists as the basic motivating force behind human behavior. Indeed, Maslow (1954) classified needs as motivators into lower and upper levels. Physiological needs such as food, clothing and shelter; and security and safety needs such as freedom from fear are on the lower level. The needs to belong (social), to be respected (ego), and to realize one's full potential (selffulfillment) are on the upper level.

Maslow noted that upper-level needs were inoperative as motivators until lower-level needs were satisfied. Moreover, once any need was satisfied it ceased to provide motivation. Haney (1967) stated that although, in general, need satisfaction follows the sequence suggested by Maslow, there are exceptions, for example, where manner of upbringing reduces a person's social-need appetite in favour of having his ego satisfied. Haney also pointed out that the utility of money in providing satisfaction diminished as one ascended the hierarchy of needs.

Because the practice of forestry favours future quality and production over immediate or short-term returns, it is said to be somewhat altruistic and is thus associated with satisfying the upper-level need for self-fulfillment. By contrast, the owner who has a medical bill or mortgage payment to meet is likely to sacrifice the future growth of young timber in exchange for immediate cash.

People do things that promise satisfaction and avoid doing things that promise dissatisfactions. (Frutchey and Williams 1965). A woodland owner will practice forestry if it offers satisfactions and if it does not interfere with other important satisfactions. For many owners, their objectives and use of land strongly emphasize nonfibre products or general recreational interests, and thus management should be measured accordingly (Olson, 1970). Many owners may derive various returns that will exceed the value of money from fibre production.

In the makeup of certain individuals there is an ethical dynamism that cannot be suppressed. In a motivational study of woodlot owners, Bofinger (1964) credited the adoption of woodlot management practices by individuals to a belief that they were doing the right thing for the land and society. Dickson (1978) was also convinced that one of the most important factors determining whether a person will manage a woodlot was the possession of a forestry ethic. He believed that it was this ethical belief in forestry, nurtured ideally in homes, schools and youth groups at an early age, that caused owners to invest their time, effort and money in the forestry venture. Bofinger further pointed out that, where this ethical belief in forestry has not been developed, woodlot owners will be more 
concerned with the income they can get out of their land than with the necessity of putting anything into it.

Bofinger also found that many woodlot owners, who possessed this ethic, were capable of deriving satisfactions through timber stand improvement, planting trees, and the personal conviction that they were doing a good job. They felt they were doing the right thing by the land, the community and their heirs, and they took pleasure in this. Such feelings seem to indicate that there is a sense of husbandry in tree farming that may be more important than the forest products themselves. Because the monetary benefits of most forest management are not immediately obtainable, nonmonetary benefits could be most important in gaining and holding owners interests in management (Murphy 1981).

The Tree farm movement, in both Canada and the United States, capitalizes on the ego-satisfying recognition of achievement in woodlot management via signs and certificates. This kind of recognition would be meaningless to an owner who had no pride of ownership or sense of stewardship with regard to his property.

Not all woodland owners practice woodlot management, and many may never do so. Bofinger (1964) implied that if a person's expectations of woodlot ownership are such that management work offers no satisfaction, no amount of time or money will encourage him to do any. Thus, it is important that owners' expectations of their woodlots be known before efforts are made to draw up and implement plans of management. According to McMahon (1964), foresters frequently look at what the woodland "needs" rather than what the owner wants. Public and private interests do not necessarily coincide. Whereas owners' interests might best be served by maximizing immediate returns through efficient exploitation, society's might best be satisfied by a deferred, optimum return over time. The "trick" here is to devise an acceptable compromise wherein both short-term and long-term goals can be achieved.

\section{Factors Influencing Owners' Expectations}

Many factors influence owners' expectations of their woodlots. The following are a few examples:

- Owners finances and how dependent owners are on their woodlands for regular or periodic income.

- Family or regional tradition of regarding the woodlot as "money in the bank" only to be used for special purchases or in times of emergency.

- The owners' knowledge of forestry and of their woodlots capability for providing goods and services.

- Owners' skills and equipment in terms of woodlot work.

- The owners' ages which not only indicate physical energy available to practise forestry, but also the length of planning horizons.

- Forestry activities including sales of timber on neighbouring properties

- Value of property for things other than timber: housing development, agricultural land, aesthetics, gravel and sand, watershed, prestige as landowners, and so forth

- Interest rate, which not only affects the cost of borrowed capital, but also the return obtainable from alternative investments.

- Taxation, in its several forms, which can affect the desirability of holding and managing wooded property.

- Availability of technical and financial assistance from government and industry.

- Size, condition and accessibility of the woodlot.

- Species, age, growth-rate, size and density of the trees present.

- Current merchantable volume and quality of the timber available for harvest.
- Insect and disease damage at present and the likelihood of its continuing to happen in the future.

- Availability of reliable logging and silvicultural contractors with appropriate equipment to harvest, as well as to do timber stand improvement and plant and tend new stands of trees.

- Whether the owners live on, or some distance from, their properties.

- Time owners have available to do woodlot work themselves.

- Home use of woodlot products.

- Size and location of markets for woodlot products plus the availability of suitable transportation.

\section{New Brunswick Private Woodlot Resources Study}

In the two-year (1981-83) New Brunswick Private Woodlot Resources Study (1983), which was primarily conducted to assess what should be done to help woodlot owners sustain an annual softwood supply of some 580000 cunits to industry, 31500 woodlot owners were surveyed. From a 30\% response, information on the characteristics and behavior of the owners was obtained. However, before sharing that information, let me describe briefly the study setting.

\section{New Brunswick}

The People. New Brunswick has a population of 700000 people divided into two major groups: French-speaking (francophones) and English-speaking (anglophones). This ethnic distinction which corresponds also to religious and political differences has made for a division of opinion and action among the province's people, but not with regard to woodlot harvesting or management.

The Forest Base. Eighty-five percent (about 15 million acres -6 million ha) of New Brunswick's land area is covered by productive forests, all of which are commercially accessible. In ownership, approximately $45 \%$ are Crown land, $23 \%$ are large industrial freeholds, and $32 \%$ are small, nonindustrial freeholds (woodlots).

The provincial forests lie within the Acadian Forest Region of Canada. Coniferous species make up about two-thirds of the volume of standing timber, deciduous species the remaining third. The spruces (Picea spp.) and balsam fir (Abies balsamea (L.) Mill.) predominate among the softwoods ( $82 \%)$, but cedar (Thuja occidentalis L.) and white pine (Pinus strobus L.) are also commercially important. The principal hardwoods include maples (Acer spp.), birches (Betula spp.), poplar (Populus spp.), and beech (Fagus grandifolia Ehrh.).

Because of past harvesting by man and budworm, the forest resource is mostly in less than ideal condition. Indeed, relative to current softwood needs of industry, operating at 90\% capacity, a shortfall in supply is predicted only 30 short years away. Intensive management, however, promises to prevent the predicted shortfall in spruce-fir pulpwood, but not the decline in sawlog and veneer-log production for a long time to come.

The small woodlots have suffered most, being only onethird to one-half as well stocked as Crown land. However, in age-class distribution they are superior to either Crown or large industrial forest.

Utilization of the Forest. Today, $80 \%$ of the New Brunswick annual wood fibre (softwood and hardwood) goes to 10 major primary wood-using companies - mainly the pulp and paper industry. The remaining $20 \%$ is used by over 100 small firms producing lumber, plywood, shingles, furniture parts, charcoal, fencing, poles, piling, flakeboard, and so on.

Provision of Woodlot Services. The woodlot has not exactly been a neglected resource in the province. A university-based extension service began in 1943 and in 1976 , the government assumed this responsibility through its Forestry Extension Service. 
Generally, programs for nonindustrial woodlots have included demonstration projects and technical assistance for the planning and development of woodlots. Financial assistance has been provided for stand improvement, access road construction, boundary line maintenance, Christmas tree and maple syrup production, and reforestation. In most programs, the owners have had to share part of the costs incurred. Small, nonindustrial woodlots have also benefited from the recent job-creation programs.

New Brunswick has also addressed the wood-marketing problem by creating seven forest products marketing boards to negotiate volumes, prices, and delivery schedules with industrial buyers. Established by a regional plebiscite of woodlot owners, the boards are financed through levies on timber sales. Their activities are monitored by a governmentappointed agency (Forest Products Commission) whose membership is drawn from industry, woodlot owners and the general public. In addition to marketing, the boards may be involved in contract administration; forest management; legislation affecting marketing, scaling, and trespassing; transportation; taxation; the export of forest products; harvesting; and the upgrading and education of woodlot owners.

\section{Now, Back to the Study ...}

The Woodlot Owners. According to the survey (Roy 1983), the average ownership was 132 acres (53 ha) with more than $66 \%$ of the owners holding from 20 to 100 acres ( 8 to 40 ha). Over three-quarters of the respondents either lived on their woodlot or within 25 miles $(40 \mathrm{~km})$ of it. About $13 \%$ were nonresidents of the province.

Approximately $40 \%$ of the respondents harvested and sold forest products in the past five years, $20 \%$ harvested and used some products for home consumption, and $40 \%$ reported not harvesting their woodlot at all. During the next five years, $71 \%$ of the owners intended to sell or use products from their woodlots.

The most common forest management activities carried out were boundary line maintenance, access road construction, improvement harvest, and thinning and spacing. Over half $(55 \%)$ of the owners undertook no forest management activities whatsoever in the past five years. In the next five years, however, $60 \%$ intended to undertake some management activity.

To permit a closer analysis of their reasons for ownership, the survey respondents were categorized according to occupation, whether they had harvested wood for sale in the past five years (producers), whether they had carried out management practices in the past five years (managers), and whether they had lived outside the province (absentee owners). Of these categories, occupation was found to have the strongest association with reasons for ownership.

Owners described their occupations as follows:

$19.2 \%$ Primary sector (fishermen, farmers, or woods workers) $21.8 \%$ Blue collar (truckers, labourers, or tradespeople)

$26.0 \%$ Pensioners (retired persons or housekeepers)

$22.0 \%$ White collar (professional or business people)

The following reasons by occupational category were given for owning forest land.

- Primary sector workers owned forest land because it was part of the farm holding, and because they were interested in producing forest products, eg. firewood, commercial timber, Christmas trees and maple syrup.

- Blue collar workers owned forest land because it was part of a permanent residence, and because they wanted to produce firewood and Christmas trees or maple syrup.

- White collar workers owned forest land because it was part of a second home, because it was a financial investment because they derived satisfaction from owning woodland, because it was used for recreation, and because they were interested in producing Christmas trees or maple syrup.

- The pensioners owned woodland because it was part of a permanent residence, because they were interested in producing firewood, and because they derived satisfaction from owning woodland.

Generally, the primary sector workers were more actively involved in harvesting and management than other categories of owners. Commercial timber production was a more important motivation for this group, and they were more able and willing to undertake forestry work themselves.

Second, there is a potential demand for contractors and skilled harvesting and forest management crews, particularly from white collar workers and pensioners. Many respondents in these categories indicated that they did not know how to sell their products or to whom, or they were unable to conduct harvesting operations owing to distance from woodlots, old age or lack of proper skills.

If contractors want to play a greater role in nonindustrial woodlot management, however, they will have to take into account the desires of woodlot owners. Nearly half the owners were dissatisfied with logging contractors, some to the extent that they would refuse to hire them again. White collar workers, pensioners, and even blue collar workers indicated that personal satisfaction, recreation and permanent residence were important reasons for woodlot ownership. Consequently, contractors must provide expanded services and train employees to recognize the requirements of small nonindustrial woodlots, whose characteristics differ significantly from those of Crown lands or large industrial holdings.

Analysis of producers, nonproducers, managers, and nonmanagers did not reveal any surprises. It did, however, confirm that past practice is a useful and reliable indicator of the owners' reasons for ownership.

Many producers apparently hold on to their property because of what they can get out of it. In fact, twice as many producers as nonproducers listed one of the following among the three main reasons for owning a woodlot: commercial timber production, firewood production, and Christmas tree or maple syrup production. More specifically, three times as many producers as nonproducers mentioned commercial timber production as one of the three reasons. Compared with producers, more nonproducers noted such reasons as personal satisfaction in owning a woodlot, recreational uses, and investment purposes.

The main reason put forward by managers for owning nonindustrial woodlots was production of forest products. Nonmanagers attached greater importance to such reasons as personal satisfaction in being an owner, investment value of a woodlot, and use for recreation.

More of the managers tended to harvest forest products. Approximately $56 \%$ of the managers sold one or more products during the last five years, compared with only $22 \%$ of the nonmanagers. However, almost twice as many nonmanagers as managers sold stumpage during the past five years. Managers sold more wood at roadside or delivered to buyers. More managers $(42 \%)$ than nonmanagers $(33 \%)$ who had hired contractors during the last five years said they were not entirely satisfied with the services.

Absentee owners' reasons for owning a woodlot did not bring any big surprises either. The reasons most frequently mentioned were, in order of importance, financial investment, personal satisfaction of owning woodland and a second home. The farther away the owner lived, the more important the woodlot as a "financial investment" seemed to become. However, over $20 \%$ of the absentee owners identified com- 
mercial timber production as one of the three main reasons for owning a woodlot.

\section{Approaches in Other Jurisdictions}

Dickson (1983) described some incentives that have been used for encouraging woodlot owners to manage their properties. These incentives are summarized in this section.

In Quebec, Nova Scotia, Europe and Japan, the problem of ownership fragmentation has been addressed through owner associations similar to those in New Brunswick. These associations prepare management plans, conduct timber sales, logging and silvicultural operations, and publish newsletters. In Quebec, diseconomies of small-scale woodlots may be overcome by the purchase of additional land through loans under the Forestry Credit Act. In Quebec and Nova Scotia, adjacent Crown land may be leased and managed in conjunction with private woodlots to make large management units.

Quebec and New Brunswick, have marketing organizations with exclusive bargaining rights, whereas Nova Scotia has a voluntary system to represent the owners in negotiating price and delivery schedules with the wood-purchasing firms. Market reports covering products sought, specifications, and prices paid are available from the US, Ontario, and various overseas governments.

A variety of technical and financial assistance programs are available in most jurisdictions that have concerns about private woodlot management.

The federal taxation system (income and capital gains taxes) applicable in Canada to small private woodlot owners is extremely complex and on the whole does not favor forest management. By comparison, some foreign jurisdictions have made extensive and effective use of the taxation system to encourage woodlot management.

Some examples of tax incentives in Europe include: a low rate of income tax or no income tax under certain specified circumstances; a simple method of assessment for income tax based on rental value of the land, yield potential or site quality; some provision for offsetting losses against income; a low rate of transfer-of-property tax or a high threshold below which no such tax is payable; deferred payment of transfer-ofproperty tax if the new owner continues to manage the holding for a minimum period in an acceptable way; and lower taxes generally if the owner complies with certain standards of management.

In reference to property taxes, private woodlots are sometimes assessed on the basis of their market value. Instead of taxing woodlots according to their market value, some jurisdictions have a fixed tax per unit of area. In Ontario, landowners can take advantage of a managed-forest property tax rebate of $50 \%$.

In the United States, at least 34 states have adopted special forest tax laws as alternatives to, or replacements for, the general property tax. All of these laws are intended to facilitate and encourage holding of land in timber growing. Recent trends have favoured a timber yield tax as opposed to the ad valorem system.

The New Brunswick property tax, as it applies to nonindustrial woodlots, currently stands at $\$ 0.80$ per hectare per year. Exemptions are also provided from gasoline taxes for defined purposes and from sales tax under the Sales Tax Act for certain items which wood producers require for harvesting or management purposes.

\section{Conclusion}

Owner expectations are the key to implementing forestry practices on the small nonindustrial woodlands of this country.
Some owners expect a financial return from their woodlot; others look for the less tangible benefits of viewing wildlife or walking and meditating in a wooded environment. Some owners know what they want; others need to be counselled because they do not know what is possible to meet their needs and interests.

Studies in various places and at various times indicate that owners are motivated, to quote McMahon (1964), by a "complex of sociological, economic and psychological influences." These influences colour the owners' needs and interests and thus the expectation of some kind of satisfaction from the ownership of a woodlot.

In the survey of New Brunswick woodlot owners (Roy 1983), variations in owner objectives, attitudes, and expectations were not only found at the regional level. A number of regional workshop participants suggested that each region usually had two or more subregions. For example, a difference existed between northern Madawaska, where woodsworkers were predominant, and southern Madawaska, which was basically a farming area. Similarly, in the southern New Brunswick region, needs and attitudes of so-called urban owners in the Saint John area were different from those of owners in the general Sussex area, which was essentially rural.

Analysis of the results of the woodlot owner survey, supplemented by consultations, led to the conclusion that there was no such thing as a typical woodlot owner, not even at the regional level, much less at the provincial level. Results pointed instead to the existence of owner categories, the mix of which varied significantly from place to place.

Consequently, one of the major conclusions drawn from the survey of New Brunswick private woodlot owners was that, because of the variations in owner objectives, attitudes and needs, regional and even subregional solutions and strategies would be needed to encourage owners to make maximum use of the forest resource.

\section{References}

Bofinger, P.O. 1964. A woodland owner survey for the Cooperative Extension Service. Univ, of $\mathrm{NH}$, Durhiam. $29 \mathrm{p}$.

Dickson, A. 1978. Forestry ethic as an incentive in North American woodlot management. Background pap. for the eighth World For. Congr. The Univ. of NB. 7 p.

Dickson, A. 1983. Motivating woodlot management in Europe and North America: a literature review. NB Priv. Woodlot Resour. Study. Fredericton. $85 p$.

Frutchey, F.P. and W.K. Williams. 1965. Motivations of small woodland owners - a summary of nine state studies. U.S. Dep. of Agric. Fed. Ext. Serv. 15 p.

Haney, W.V. 1967. Communication and Organizational Behavior Text and Cases. Richard D. Irwin, Inc., Homewood, III. 534 p.

Maslow, A.H. 1954. Motivation and Personality. Harper and Brothers, New York. 396 p.

McMahon, R.O. 1964. Private nonindustiral ownership of forest land Yale Univ. Bull. No. 68.122 p.

Murphy, D.P. 1981. Factors related to the adoption of woodlot practices by the Fredericton city-resident woodlot owner. M.Sc.F. diss. Univ. of NB. 246 p.

New Brunswick Private Woodlot Resources Study. 1983. Private Woodlots: what does the future hold? NB Private Woodlot Resour. Study, Fredericton. $119 \mathrm{p}$.

Olson, D.D. 1970. An educational program for absentee landowners Dep. of Resour. Dev. Mich. State Univ., East Lansing. 22 p.

Roy, P. 1983. New Brunswick nonindustrial woodlot owner survey Background Pap. NB Private Woodlot Resour. Study, Fredericton. 209 p.

Shirley, H.L. 1952. Forestry and its Career Opportunities. McGraw-Hill Book Co., Toronto. 454 p. 